\title{
Mastitis Causing Pathogens within the Dairy Cattle Environment
}

\author{
Ayuba Caleb Kudi (Corresponding Author), M.P. Bray \& Aziwo.T.Niba \\ Faculty of Science, School of Biological Sciences, University of Plymouth \\ Drake Circus, Plymouth, Devon PL 4 8AA, United Kingdom \\ E-mail: akudi@plymouth.ac.uk \\ Demo.J.U.Kalla \\ Animal Production Programme, Abubakar Tafwa Balewa University \\ P.M.B.0248 Bauchi 740004, Bauchi State \\ E-mail: demokalla71@yahoo.com
}

\begin{abstract}
The aim of this study was to investigate the relationship between bacterial numbers found within the bedding material and those found upon the teats in cattle herds bedded on three different bedding materials; sand, sawdust and straw. The bacteria to be studied are known to be responsible for the development of mastitis within the mammary glands resulting in reduced milk quality and poor welfare conditions for the animal. Samples for the analysis were collected under natural housing conditions from the bedding and from the teats of a representative sample of each herd. These were then plated to isolate numbers of the environmental bacteria, Streptococcus uberis and Escherichia coli (E. coli), and to conduct a total viable count for comparison. Statistical analysis showed that six of the nine relationships tested resulted in a $\mathrm{P}<0.05$. The microbial test results also showed that the straw bedding hosted the lowest total number of bacteria at $8.5 \times 10$. When compared with the incidence of mastitis infections within the herd, the straw bedding had a considerably higher number of infections than from the sand or sawdust with thirty-one cases recorded. In conclusion, minimising pathogen growth within the bedding material, results in lower numbers of pathogens being transmitted onto the cow's teats thereby reducing the possibility of intrammamary infections. It is recommended that further work is carried out through repeating the study on a larger number of farms to identify whether the relationship between the bacterial numbers exists on further farms. In addition to this, it is also recommended that further analysis of the pathogens responsible for the mastitis within the herds be undertaken to identify if the environmental pathogens are responsible for these intrammamary infections.
\end{abstract}

Keywords: Environmental mastitis, Strep uberis, E.coli, Sand, Sawdust, Straw, Clinical mastitis

\section{Introduction}

Mastitis (Mast: breast, itis: inflammation) is defined as 'an inflammation of the udder resulting in an inflamed quarter or quarters with a change in the appearance of the milk' (Blowey 1999). Mastitis can either be infectious, caused as a response to the presence of microbial organisms or non-infectious, as a result of physical injury to the mammary gland. The inflammatory response results in an increase in the blood proteins and white blood cells in the mammary tissue, which can then pass into the milk product. This response aims to destroy the irritant, repair the damaged mammary tissue and return the udder to its normal function. However, as a result of such mastitic inflammations, a loss in milk output is often experienced (Table 1).

Economic losses from mastitis infections to the National Dairy Herd are estimated at $£ 93$ million per year to the UK Dairy Industry through discarded milk, quality penalties, treatment and reduced output (Kossaibati \& Esslemont 1997). It has been calculated by Esslemont (2002) that a single mild case of mastitis can cost almost $£ 150$ through direct and indirect costs. The quality of milk is affected in a number of ways (Table 2) including composition such as fat and protein and also through the increase in somatic cells that can lead to penalties imposed by milk buyers. Edmondson (2004) states that 'high cell counts result in farmers losing money: 0.3ppl, which is the minimum penalty, is the equivalent of $£ 20$ per cow per year'. In addition to this, Edmondson (2004) also states that 'low cell count milk tastes 
good, has a longer shelf life for the consumer and gives maximum value to the processor,' whilst mastitic infections can also lead to reductions in the components important to human health such as calcium and potassium.

The inflammatory response to mastitic infections also gives rise to welfare issues within the herd with inflammations of the udder causing undue pain and discomfort for the animal, whilst severe cases can lead to poisoning and premature death (Blowey 1999). In terms of the sources of infection it has been established that bacteria are the most common cause of mastitis although other sources of infection including mycoplasms, algae and fungi, are also prevalent (Cassel 1993). There are several species of such infectious bacteria responsible for causing these infections including Staphyloccocus aureus, Streptococcus agalactaie, Streptococcus dysgalactiae, and the environmental bacteria, E. coli and Streptococcus uberis.

The simple classification of mastitis recognises two major groups; environmental mastitis and contagious mastitis. Environmental mastitis, which is to be examined within this study, is caused by organisms such as E. coli and Streptococcus uberis that do not usually live upon the skin but enter the teat canal when the cow comes into contact with a contaminated environment. Further divisions between the two groups can be made including clinical, sub-clinical and chronic mastitis. Mustafa (2003) states that only a small proportion of udder infections result in "clinical mastitis" whereby there are changes in udder condition and milk quality. The vast majority of cases exist as sub-clinical; with an estimated 20 - 40 cases for every clinical mastitis case within the herd. Therefore mastitic problems may be present within a herd despite no visible presence within the cows or the milk.

Edmondson (2001) states that 'environmental infections account for nearly two-thirds of all cases of clinical mastitis,' with the infection occurring either between milkings, such as teat contact with pathogenic material, or during the udder preparation. Dodd (1987) states that 'contamination with the teat end of a susceptible quarter from a pathogen is the first stage in the infection process' and thus the problem of environmental bacteria from contaminated material is one of great concern within the dairy sector.

A study conducted by Rendos, Eberhart \& Kesler (1975) identified that different bedding materials influenced the types and numbers of bacteria within such materials whilst a later study by Ward, Hughes, Faull, Cripps, Sutherland \& Sutherst (2002) studied the effects of straw bedding upon the incidence of mastitic infections from environmental pathogens. The aim of this study, however, is to use three different bedding materials sand, sawdust and straw to examine the relationship between the bacterial numbers within the bedding material and the bacterial numbers found upon the teats within each herd. The results of this investigation will also be compared against the incidence of mastitis within the herd to identify the suitability of these bedding materials in the aim of reducing mastitic infections. This study will examine the two most prevalent environmental bacteria, E. coli and Streptococcus uberis to identify ways to reduce mastitic infections caused by such bacteria.

\section{Materials and Methods}

\subsection{Site selection}

The farms were chosen based on their use of the three bedding materials; sand, sawdust or straw, their daily routine within the cubicle housing and the herd number. Each farm removes faeces from cubicles, rakes the bedding material about and cleans the dunging areas twice each day ensuring adequate cleanliness and similarities between the three farms. Farm size and average cell count can be seen in Table 3.

These similarities between farms allow the relationships between bacterial numbers to be more fairly compared under such natural conditions. It is necessary to highlight the difference in the addition of new bedding materials to the cubicles; the farms using sand and sawdust both apply fresh bedding to cubicles on a weekly basis whilst straw is added fresh on alternative days at the straw bedded farm. Although there is a difference in the addition of fresh bedding between the three farms, each farm rakes cubicles about daily to provide cleaner material to the area in contact with the udder. The difference in bedding styles will also show the effects upon bacterial numbers of applying fresh bedding on a regular basis in comparison with the weekly applications.

\subsection{Collection of samples}

Bedding Samples - Every fourteen days five samples of each bedding material were collected on the day of plating to ensure minimal bacterial change between the collection and plating processes. Samples of approximately 30 grams of bedding were collected from the area of the cubicle in contact with the cow's udder and placed into sterilised bags before being sealed to prevent contamination.

Teat Samples - At the fourteen day intervals five teat swabs were also collected from each farm. This was carried out during the milking process with all cows dry wiped before sample collection to remove loose bedding debris. A single teat from each cow was sampled using a moistened sterilised swab rotated over the teat end five times before being placed into a bottle of $10 \mathrm{ml}$ diluents for transport. 
All of the samples were then transported from farm to laboratory under low temperature conditions to reduce bacterial change before being plated.

\subsection{Procedures for microbial analysis - plating techniques}

\subsubsection{Plating bedding samples}

Under aseptic conditions within the laboratory 10 grams of the bedding material was transferred from the collection bag into a sterilised stomacher bag with $90 \mathrm{ml}$ of diluent added, this was then placed in a macerator for 30 seconds to remove the bacterial species from the bedding material. The solution produced represented a $10^{-1}$ sample of the bacteria present within the bedding material with further dilutions made down to $10^{-8}$ using $1 \mathrm{ml}$ of the previous dilution to $9 \mathrm{ml}$ of diluent. A $0.2 \mathrm{ml}$ sample of the required dilution was then placed onto the selected agar plate and spread over the entire surface. After this was carried out upon on all samples, the agar plates were incubated for 24 hours before inspection and analysis. Table 4 displays the dilutions used for each bedding material.

\subsubsection{Plating teat samples}

Under aseptic conditions, the teat samples were agitated for 10 seconds to extract the bacteria from the swab before a sample was taken. One millilitre of the solution was taken for use in producing dilutions down to $10^{-3}$, with a $0.2 \mathrm{ml}$ sample taken for spreading upon the bacteria specific agar plates. Table 5 displays the dilutions used for the microbial tests upon the teats from each type of bedding.

\subsubsection{Analysis of bacteria specific agar plates}

The agar plates were incubated for 24 hours at $37^{\circ} \mathrm{C}$ before being removed for inspection and counting using a tally counter. Isolation of the bacteria required was carried out through the use of the bacteria specific agar plates, these being MacConkey agar to isolate E. coli bacteria and the Edward's medium agar to isolate the Streptococci bacteria. Further isolation of the Streptococci uberis strain was carried out through the exposure of plates to ultra-violet light to which Strep, uberis appears dark black, whilst the clear agar and other Streptococci strains become pink. After the bacteria are counted, calculations need to be undertaken to identify the bacterial content in $1 \mathrm{ml}$ of the neat sample. This is carried out through multiplication by five to change the samples from $0.2 \mathrm{ml}$ to $1 \mathrm{ml}$ samples, these can then be multiplied by the dilution factor to identify the bacterial number within a $1 \mathrm{ml}$ sample.

\section{Results}

From each farm the five results were recorded with the mean calculated for each of the sampling periods. These sampling periods were conducted at two week intervals over a three month period to provide data at regular stages whilst the cows are housed during winter. From these six results the mean was calculated for each farm and each microbial test for use within the tabulated and graphical comparisons. For statistical tests the six results were used to provide a larger data source for better comparison.

\subsection{Statistical analyses}

The data was analysed using MINITAB 13 to compare the teat and bedding data. The first test was used to identify whether the data was significantly different between the three farms, was analysed using the Analysis of Variance (ANOVA) test. A further test, the two-sample t-Test, was used to ascertain the relationship between the numbers of bacteria found within the bedding and those found upon the teat ends.

\subsection{Bedding material results}

The results above show no significant difference between the data for the E. coli and total viable count with $\mathrm{P}>0.05$. The Strep, uberis test results in a $\mathrm{P}$-value of only slightly above this significant value with $\mathrm{P}=0.051$ resulting in the possibility of some degree of difference between the data sets. The mean results for each microbial test conducted can be best viewed when displayed within a histogram (Figure 1).

The graph above identifies that the material hosting the lowest Strep, uberis and total bacterial number was the straw. The sand bedding has a slightly lower total viable count (TVC) than that of the sawdust although has the highest number of Strep, uberis bacteria compared with the straw and sawdust materials. Further analysis of the E. coli data can be viewed in Figure 2.

Further graphical analysis of the E. coli bacteria on a smaller scale identifies that the material hosting the greatest number of $E$. coli bacteria is the sawdust which has three times the amount found within the sand bedding and twice as many as found within the sawdust.

\subsection{Teat end results}

The results from the ANOVA test show there to be no significant difference between the data for each microbial test conducted with values of $P>0.05$. The mean results from the microbial tests can be viewed graphically in Figures 3 and 4 .

The histogram displays the straw bedding to be the most suitable form of bedding material for reducing total bacterial 
numbers (TVC) and Strep, uberis numbers upon the teat. The sand suit in high numbers of Strep, uberis upon the teat ends. By examining the total viable count for the sawdust material it can be seen that it is considerably higher than that of either the sand or straw bedding materials. Again closer analysis of the E.coli data needs to be undertaken which can be seen in Figure 4.

After closer graphical analysis of the E.coli bacteria upon the teat ends, the numbers of E.coli bacteria can be seen to be considerably higher within the sand and sawdust materials than from within the straw bedding.

\subsection{Further tests}

Two additional tests were also carried out to identify possible sources for the environmental bacteria. These tests included testing the drinking water to ensure this was not a possible source of infection and secondly through examining the unused bedding material for bacterial numbers.

\subsection{Water testing}

The water was sampled from its source and tested for bacterial presence. After testing it was established that two of the farms, those using sand and sawdust, had shown positive for bacterial presence and thus further isolation of the bacterial species was required. Further analysis identified that the sawdust sample indicated negative for the presence of E.coli whilst the sand sample indicated positive. However, after through this analysis it was identified that the presence of bacteria was below the requirements set for mains water supply and thus not a potential source for such environmental mastitis pathogens.

\subsection{Tests on unused bedding}

A further test was carried out upon the unused bedding prior to be added to the cubicles with the results shown in Table 8 .

These results identify that the unused bedding materials are potential sources of mastitic infection prior to use. Therefore in the housing conditions these bacteria are at their optimum $\mathrm{pH}$, temperature and have available food sources from the organic bedding materials therefore encouraging rapid bacterial growth resulting in possible infections of the mammary gland.

\subsection{Analysis of the relationship}

\subsubsection{Comparison of the data - two sample t-test}

The main aim of this study was to identify the relationship between the bacterial numbers found within the bedding and those found upon the teat ends of cows from each of the three bedding materials. This relationship analysis was carried out using MINITAB 13 and the Two sample t-test. The results of this test are shown displayed in Tables 9, $10 \& 11$.

The Two sample t-test identified a significant relationship between the numbers of bacteria in two-thirds of the nine relationships tested with $\mathrm{P}<0.05$. The three remaining relationships do not show a significant relationship with $\mathrm{P}>0.05$ although the P-values formed as a result are still relatively low at between 0.072 and 0.103 which may be due to anomalous data from faeces or wetter bedding. The relationships established show a distinct relationship for the bacteria Strep, uberis within all three bedding materials. Whilst in contrast the E.coli relationships identify only the sand as having a significant relationship with the $\mathrm{P}=0.072$ and 0.103 for the sawdust and straw respectively. In addition, the total viable count carried out identifies significant relationships between data for both the sand and straw material, whilst the sawdust $\mathrm{P}$-value is slightly greater than the significant value with $\mathrm{P}=0.073$.

\section{Discussion}

Work carried out by Blowey (1999) and a study by Ward et al. (2002) have established that a relationship exists between bacterial numbers within bedding materials and the incidence of mastitis infections within the herd. A further study by Rendos et al. (1975) identifies similar links, as found within this study, between bedding and bacteria numbers, although their study was carried out upon different bedding materials. This study however aims to identity whether there is a direct relationship between the bacteria upon the teat ends and those found within the three different bedding materials of sand, sawdust and straw. Through the analysis of the data collected from the three farms this study has identified that the straw bedding hosts the lowest number of Strep, uberis and the total viable count whilst the sand bedding hosts the lowest numbers of $E$. coli (Table 6). In contrast the sawdust bedding hosts high numbers of both environmental bacteria and the total viable count. On the second test upon the cow's teat ends the straw bedding again hosted the lowest numbers of environmental bacteria whilst the sand bedding hosted the lowest numbers of bacteria within the total viable count (Table 7). Examining this data it would appear that the straw bedding appears to be the most suitable bedding material for reducing bacterial numbers, both within the bedding and upon the teat ends, whilst the sawdust appears to be the worst. The reason for the poor performance of the sawdust is due to its small particle size which, being organic, encourages the rapid growth of bacteria. This small particle size is also said to allow greater contact with teat ends increasing the risk of new infections (Godkin 2002). In terms of the performance of the straw it is important to note that, although the straw bacterial numbers are the lowest recorded, the regular renewal of bedding 
materials will result in reduced bacterial growth within the bedding. The additional test carried out upon the unused bedding identifies the sand bedding material as having the lowest numbers of bacteria when looked at overall, whilst the straw material appears to host exceptionally high numbers of environmental bacteria and has a considerably high total viable count (Table 8). The unused bedding may therefore be a major source of environmental bacteria, with such bacteria capable of surviving for long periods and remaining viable between $15-45^{\circ} \mathrm{C}$ with $\mathrm{pH}$ conditions up to 9.5 , with damper bedding materials promoting greater growth of bacteria increasing the level of contamination of the teat ends (Godkin 2002).

Based on the information, it is worthwhile comparing the results from the experiments with the occurrence of mastitic infections within each herd to identify the most suitable type of bedding for reducing clinical infections (Table 12).

As shown in Table 12 the straw bedding material has the highest number of clinical mastitis cases in comparison with the sand bedding, which experiences the lowest number of mastitis cases over the sampling period. This is in contrast with the data from the microbial tests conducted from the housing conditions which would have tended to indicate that the straw, which experienced low bacterial numbers both within the bedding and upon the teat ends, would have reduced mastitic infections. An explanation for this is the inert nature of the sand material which does not support bacterial growth as it has little or no nutritive value to sustain bacterial development, (Reader 2003) whilst within the laboratory conditions these bacteria are allowed nutritive agar and thus begin to grow and develop. Thus under the housing conditions these bacterial numbers would remain low due to lack of nutritive availability. Sand, unlike straw and sawdust, does not heat up and does not support moisture to the same extent and therefore does not allow the optimum growth of bacteria to occur (Reader 2003). If the straw bedding had been used in a week long period however, bacterial growth would have been expected to be far higher due to the accumulation of bacterial growth from increased temperatures, moisture and nutritive value in the form of straw, resulting in the possibility of additional cases of mastitis within the herd.

The main aim of this study was to identify whether a relationship exists between the bacterial numbers within the bedding materials and the numbers of bacteria upon the teat ends. The analysis of the data using the Two sample t-test identified significant relationships in $66 \%$ of the bedding material and teat end relationships, with the resulting $33 \%$ slightly above the significant $\mathrm{P}=0.05$. It is therefore apparent, that through minimising the growth and development of pathogens within the bedding material, numbers of mastitic pathogens upon the teat ends can also be reduced, resulting in the possibility of fewer intramammary infections.

\section{Conclusion}

In conclusion, this study has identified that a relationship exists between the bacterial numbers within the bedding materials and those found upon the teat ends. As a result, by aiming to reduce bacterial numbers within the bedding materials, the number of infectious bacteria upon the teat ends can be reduced leading to a possible reduction in intramammaiy infections from the contact of teat ends with infectious bacteria.

This study also identified straw as being host to the lowest number of bacteria on an overall basis, whilst sawdust appeared to harbour the most. Regular renewal of the straw bedding on alternative days explains the resulting lower bacterial numbers than within the weekly bedded sand or sawdust. It is expected, from research into literature surrounding the subject, that sand is the most suitable type of bedding material for reducing clinical mastitis within the cow environment, which is also supported by the results in Table 12. Increasing the frequency of new cubicle bedding within the farms using sand and sawdust would help to reduce the accumulation of environmental pathogens and further reduce the chance of mastitic infections.

From the analysis of the results and available literature, there are a number of possible ways to reduce intramammary infections. This study has highlighted the importance of the regular change of bedding upon reducing bacterial numbers and has also identified the effects of bedding material type upon the incidence of mastitic infections within the herd. Through reducing mastitic pathogens within the bedding material, it has also been shown that the transfer of pathogens onto the susceptible teat ends can be reduced allowing the animal's own defence mechanisms to manage such infections more effectively. Through the reduction of incidence in these intramammary infections, advantages can be seen for the consumer; through improved milk quality and longer shelf life, the processor; through improved quality of milk for cheese making and to the producer; through reduced costs from dealing with clinical cases and through the improved milk quality, resulting in reduced penalties.

\section{Recommendations for further work}

Recommended further work includes expanding the research to incorporate a wider range of farms to gain greater reliability within the data. Additional bedding materials could also be included within the research to include newer materials such as paper, wood pulp or rubber mats.

Further work could also be carried out to analyse the types of bacteria causing the clinical mastitis infections to identify whether such infections are caused by the same environmental bacteria found within the bedding materials. This would 
identify whether a relationship exist between the bedding materials and the mastitic infections.Mastitis is a vast subject to study and therefore there is a large amount of further work that still needs to be undertaken to understand the subject fully.

\section{References}

Blowey, R. and Edmondson, P. (1995). Mastitis control of dairy herds. Farming Press Books, London.

Blowey, R.W. (1999). A Veterinary book for dairy farmers, $\left(3^{\mathrm{r}} \mathrm{Ed}\right)$. Farming Press Books, London.

Cassel, E. K. (1993). Mastitis control, Reducing somatic cell counts. [Online] http://www.abs.sdstate.edu/flc/foodsafetv/safety/mastitis.htm (14.10.2003).

Cook, N.B. (2001). How good is sand bedding for your cows?. Hoard's Dairyman, 146(18), 667.

Dodd, F. (1987). Environmental influences in bovine mastitis. International Federation No. 217/1987.

Edmondson, P. (2001). Environmental mastitis, A matter of control. Dairy Farmer, 48 (5), 14-15.

Edmondson, P. (2004) Celling out. Express Milk Partnership, Express Dairies, April-04, p16.

Esslemont, D. (2002). What is mastitis really costing you? Dairy Farmer, 49 (12), 30 -31.

Godkin, G. (2002). Feeding for higher production may be linked to environmental mastitis. [Online] http://www.govonca3.gov.on.ca/OMAFRA/english/livestock/dairy/facts/mfo feeding.htm (13.10.2003).

Hughes, J. (1999). Bedding systems and mastitis. Proceedings of the British Mastitis Conference(1999), p73-78. [Online] http://www.iah.bbrsc.ac.uk/bmc/1999/papers\&posters1999/Hughes.doc (14.10.2003).

Kossaibati, M. A. and Esslemont, R. J. (1997). The costs of production diseases in dairy herds in England, Proceedings of British Mastitis Conference 1997: Progress in Mastitis Control, 8 October 1997. [Online] http://www.iah.bbsrc.ac.uk/bmc/1997/1997 papers - wordppl-14 kossaibati.doc.

Mustafa, A. (2003). Mastitis in dairy cows; Dairy cattle production 342-450A. Macdonald Campus of Mcgill University, Faculty of Agricultural \& Environmental Sciences, Department of Animal Science.

Reader, J. (2002). Sand is clean, cool and comfortable but. Dairy Farmer, 49 (11), 50 - 53.

Rendos, J.J. Eberhart, R.J. and Kesler E.M., (1974).Microbial populations of teat ends of dairy cows, and bedding materials. Journal of Dairy Science, 58, 1492 - 1500.

Ward W.R, Hughes J.W, Faull W.B, Cripps P.J, Sutherland J.P, Sutherst J.E. (2002). Observational study of temperature, moisture, $\mathrm{pH}$ and bacteria in straw bedding and faecal consistency, cleanliness and mastitis in four dairy herds. Veterinary Record, 151, $199-206$.

Table 1. Loss in milk yield as a result of mastitis infections

\begin{tabular}{cc}
\hline Somatic cell count & Loss of milk (\%) \\
$<200,000$ & $0-5$ \\
$200,000-500,000$ & $6-9$ \\
$500,000-1,000,000$ & $10-18$ \\
$>1,000,000$ & $19-29$ \\
\hline
\end{tabular}

Source: (Mustafa, 2003) 
Table 2. Changes in milk composition associated with mastitis

(Source: Mustafa, 2003)

\begin{tabular}{llcc}
\hline & Normal Milk & Mastitic Milk \% of normal \\
\hline Solid-not-fat & 8.98 & 8.8 & 99 \\
Fat & 3.50 & 3.20 & 91 \\
Lactose & 4.90 & 4.40 & 90 \\
Total protein & 3.61 & 3.56 & 99 \\
Total casein & 2.80 & 2.30 & 82 \\
Whey protein & 0.80 & 1.30 & 162 \\
Serum albumin & 0.02 & 0.07 & 350 \\
Lactoferrin & 0.02 & 0.10 & 500 \\
Immunoglobulins & 0.10 & 0.60 & 600 \\
Sodium & 0.06 & 0.105 & 184 \\
Chloride & 0.09 & 0.147 & 161 \\
Potassium & 0.17 & 0.157 & 91 \\
Calcium & 0.12 & 0.04 & 33 \\
\hline
\end{tabular}

Table 3. Herd numbers and cell counts within the three selected farms

\begin{tabular}{ccc}
\hline & Average Cell Count (,000) & Herd Size \\
\hline Sand & 219 & 120 \\
Sawdust & 228 & 113 \\
Straw & 223 & 117 \\
\hline
\end{tabular}

Table 4. Dilutions used for different bedding materials

\begin{tabular}{lccc}
\hline & Sand & Sawdust & Straw \\
\hline E. coli & $10^{-5}$ & $10^{-8}$ & $10^{-8}$ \\
Strep. uberis & $10^{-5}$ & $10^{-8}$ & $10^{-8}$ \\
Total Viable Count & $10^{-5}$ & $10^{-7}$ & $10^{-8}$ \\
\hline
\end{tabular}

Table 5. Dilutions used for teat samples

\begin{tabular}{lccc}
\hline & Sand & Sawdust & Straw \\
\hline E. coli & Neat (no dilution) & Neat (no dilution) & Neat (no dilution) \\
Strep. uberis & $10^{-3}$ & $10^{-3}$ & $10^{-2}$ \\
Total Viable Count & $10^{-3}$ & $10^{-3}$ & $10^{-3}$ \\
\hline
\end{tabular}

Table 6. Mean and ANOVA results of bacteria within three bedding materials

\begin{tabular}{|c|c|c|c|c|c|c|}
\hline & E. coli & StDev. & Strep, uberis & StDev. & Total Viable Count & StDev. \\
\hline Sand & $2.3 \times 10^{6}$ & $9.1 \times 10^{5}$ & $4.0 \times 10^{10}$ & $3.6 \times 10^{10}$ & $\mathrm{Ux}^{11}$ & $9.1 \times 10^{10}$ \\
\hline Sawdust & $8.4 \times 10^{6}$ & $9.0 \times 10^{6}$ & $2.1 \times 10^{10}$ & $1.8 \times 10^{10}$ & $1.3 \times 10^{11}$ & $1.4 \times 10^{11}$ \\
\hline Straw & $3.4 \times 10^{6}$ & $4.1 \times 10^{6}$ & $3.1 \times 10^{9}$ & $2.7 \times 10^{9}$ & $8.5 \times 10^{1-}$ & $6.2 \times 10^{10}$ \\
\hline P-Value & 0.186 & & 0.051 & & 0.743 & \\
\hline
\end{tabular}


Table 7. Mean and ANOVA results of teat end bacteria from the three bedding materials

\begin{tabular}{lcccccc}
\hline & E. coli & StDev. & Strep, uberis & StDev. & Total Viable Count & StDev. \\
\hline Sand & 43.1 & 92.4 & $5.4 \times 10^{5}$ & $1.2 \times 10^{6}$ & $3.4 \times 10^{5}$ & $3.0 \times 10^{5}$ \\
Sawdust & 25.8 & 15.3 & $4.7 \times 10^{6}$ & $1.0 \times 10^{7}$ & $1.7 \times 10^{6}$ & $3.0 \times 10^{6}$ \\
Straw & 1.6 & 2.2 & $1.0 \times 10^{4}$ & $1.8 \times 10^{4}$ & $1.3 \times 10^{5}$ & $2.3 \times 10^{5}$ \\
& & & & & & \\
P-Value & $0.431(\mathrm{~ns})$ & & $0.388(\mathrm{~ns})$ & &
\end{tabular}

Table 8. Results of bacterial numbers in unused bedding

\begin{tabular}{llll}
\hline & Sand & Sawdust & Straw \\
\hline Strep. uberis & $1.9 \times 10^{3}$ & $2.4 \times 10^{\mathrm{J}}$ & $9.3 \times 10^{4}$ \\
E.coli & $1.0 \times 10^{2}$ & 0 & $3.5 \times 10^{2}$ \\
& & & \\
Total Viable Count & $4.0 \times 10^{5}$ & $5.1 \times 10^{5}$ & $2.9 \times 10^{6}$
\end{tabular}

Table 9. P-Values from the Two sample t-test for the sand bedding

\begin{tabular}{lcccc}
\hline & Mean & StDev. & Sand P-Value & Significance \\
\hline E. coli & $2.3 \times 10^{6}$ & $9.1 \times 10^{5}$ & 0.001 & $* * *$ \\
Strep. uberis & $4.0 \times 10^{10}$ & $3.6 \times 10^{10}$ & 0.043 & $* *$ \\
Total Viable Count & $11 \times 10^{11}$ & $9.1 \times 10^{\mathrm{IU}}$ & 0.031 & $* *$ \\
\hline
\end{tabular}

$(* * *=\mathrm{P} 0.001, * *=\mathrm{P}<0.05, \mathrm{~ns}=$ not significant $)$

Table 10. P-Values from the Two sample t-test for the sawdust bedding

\begin{tabular}{lcccc}
\hline & Mean & StDev. & Sawdust P-Value & Significance \\
\hline E. coli & $8.4 \times 10^{6}$ & $9.0 \times 10^{6}$ & 0.072 & $\mathrm{~ns}$ \\
Strep. uberis & $2.1 \times 10^{\mathrm{ltJ}}$ & $3.6 \times 10^{\mathrm{lu}}$ & 0.040 & $* *$ \\
Total Viable Count & $1.3 \times 10^{\prime \prime}$ & $1.4 \times 10^{\prime \prime}$ & 0.073 & $\mathrm{~ns}$ \\
\hline
\end{tabular}

$(* * *=\mathrm{P} 0.001, * *=\mathrm{P} 0.05, \mathrm{~ns}=$ not significant $)$ 
Table 11. P-Values from the Two sample t-test for the straw bedding

\begin{tabular}{|c|c|c|c|c|}
\hline & Mean & StDev. & Straw P-Value & Significance \\
\hline E. coli & $3.4 \times 10^{6}$ & $4.1 \times 10^{6}$ & 0.103 & ns \\
\hline Strep. uberis & $3.1 \times 10^{9}$ & $2.7 \times 10^{y}$ & 0.037 & $* *$ \\
\hline Total Viable Count & $8.5 \times 10^{10}$ & $6.2 \times 10^{10}$ & 0.021 & $* *$ \\
\hline
\end{tabular}

Table 12. Cell Count and Mastitis incidence during the sampling period

\begin{tabular}{lll}
\hline & Mean Cell Count & Clinical Mastitis Cases \\
\hline Sand & 223,000 cells $/ \mathrm{ml}$ & 14 \\
Sawdust & 230,000 cells $/ \mathrm{ml}$ & 23 \\
Straw & 234,000 cells $/ \mathrm{ml}$ & 31 \\
\hline
\end{tabular}

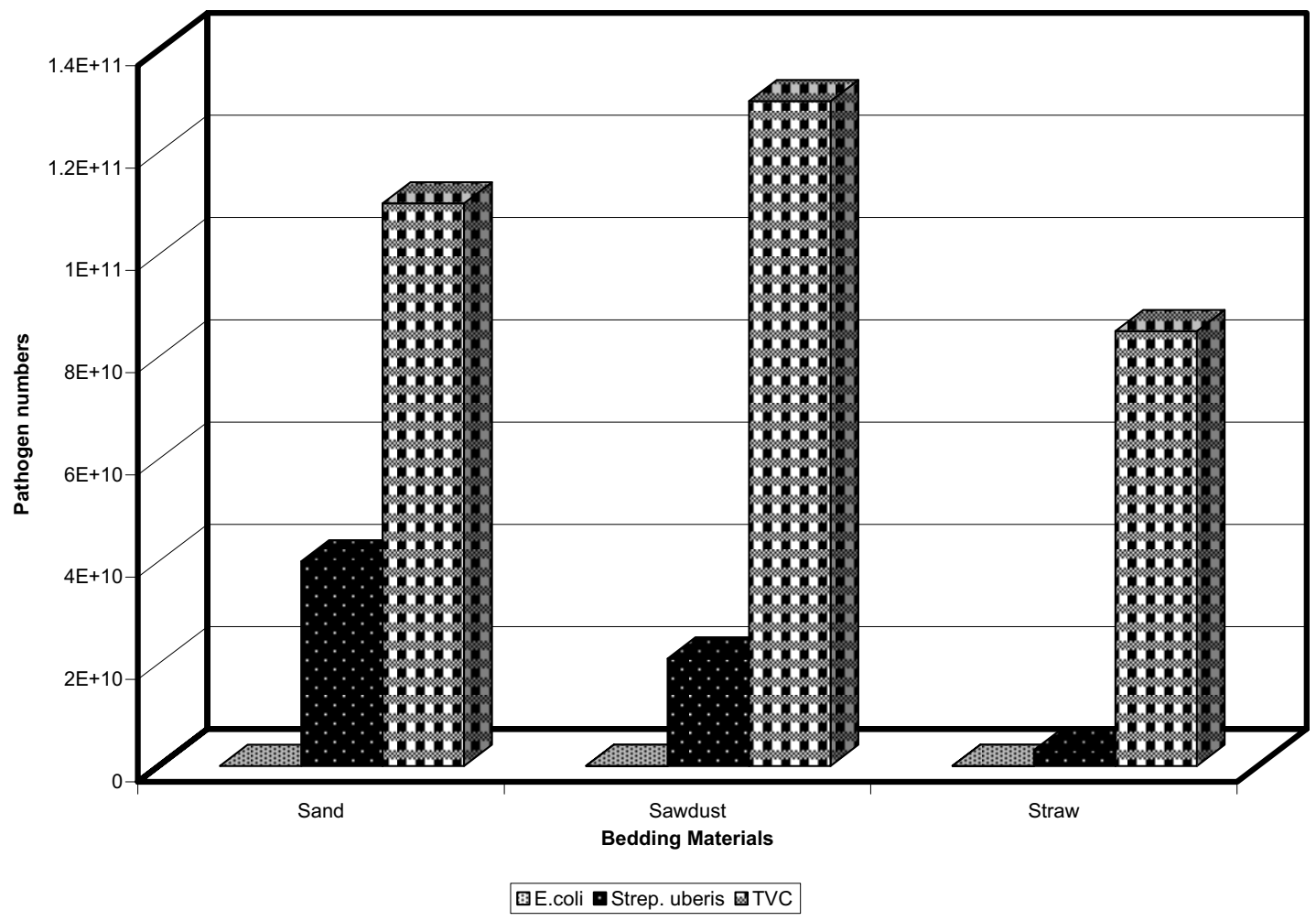

Figure 1. Histogram of bacterial numbers within the three bedding materials 


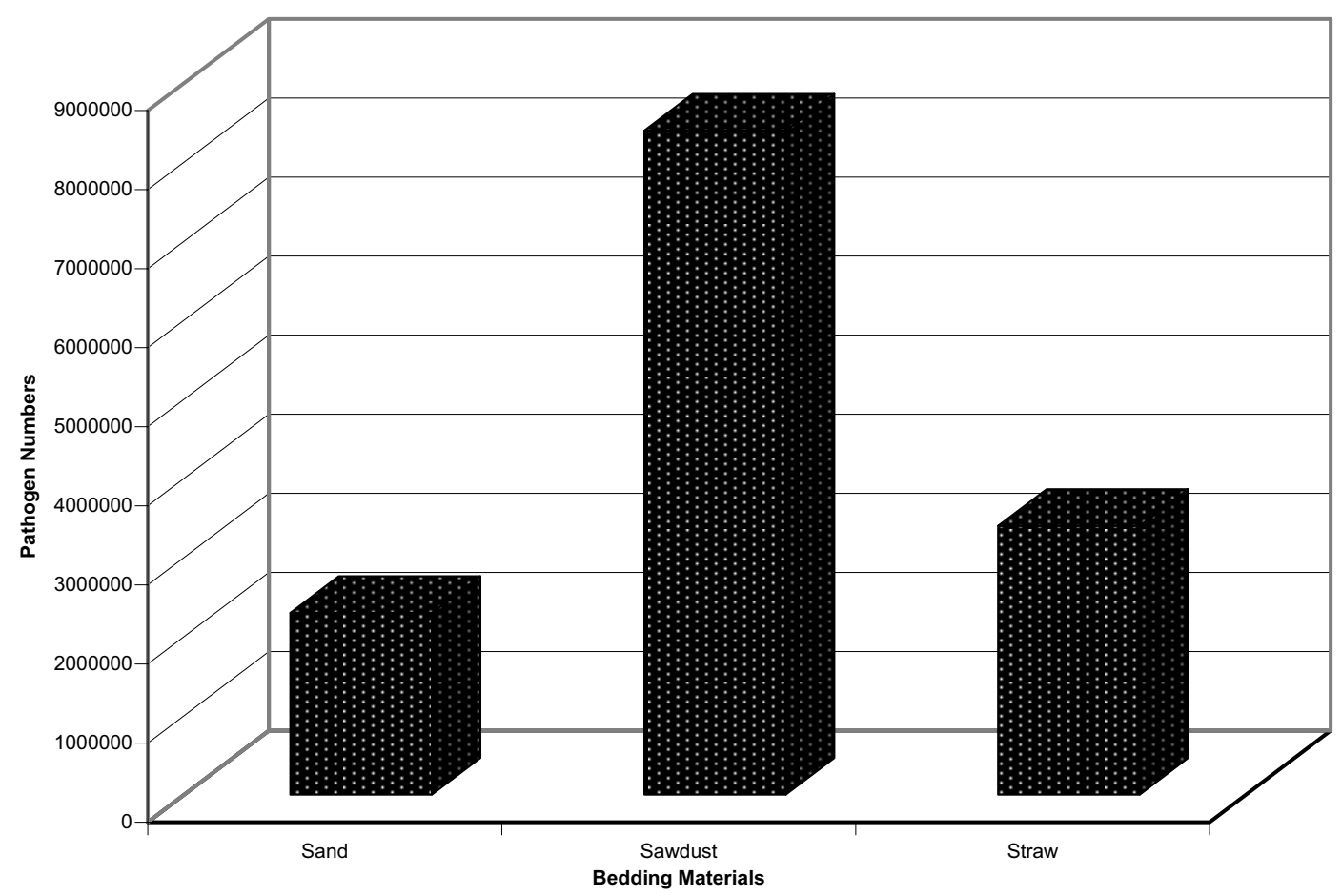

Figure 2. Histogram of E. coli numbers in the three different bedding materials

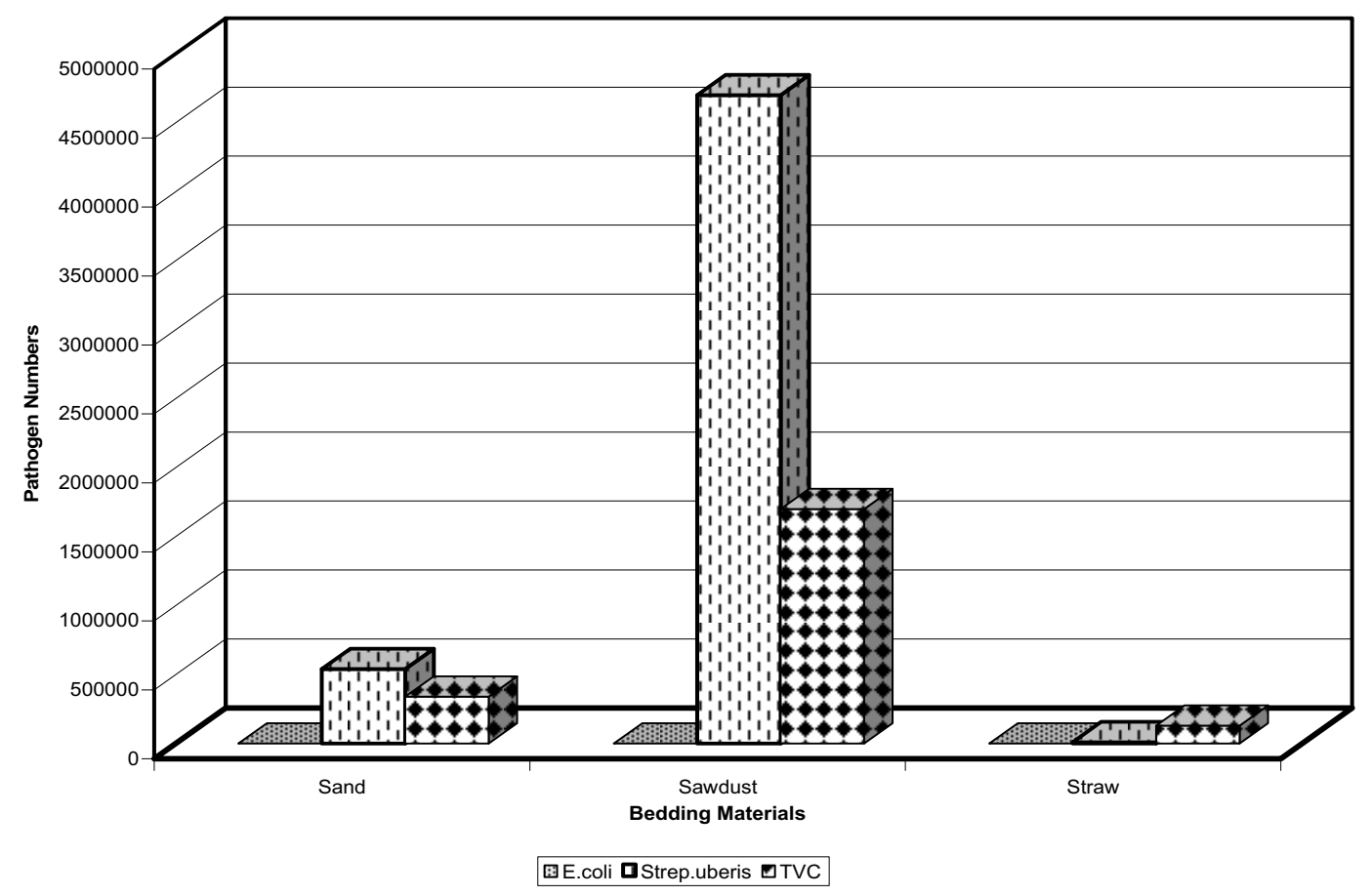

Figure 3. Histogram of the bacterial numbers upon the cow teats from each bedding type 


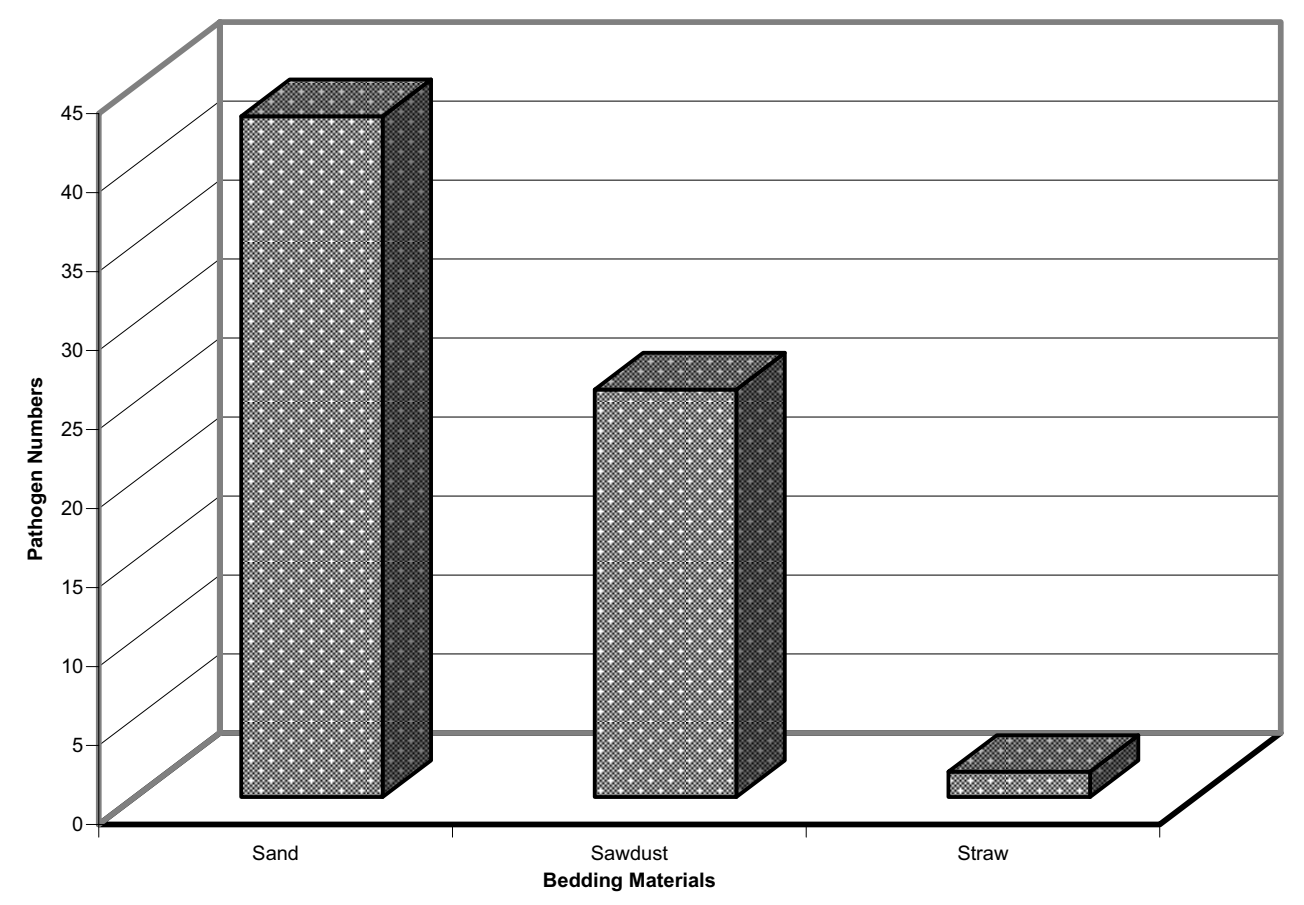

Figure 4. Histogram of E. coli numbers upon the cow teats from the three different bedding materials 